\title{
Epidemiological situation of human leptospirosis in Brazil and challenges in its diagnosis with a focus on molecular approaches
}

\author{
Andressa Penedo de Paiva Estrella \\ Amanda Silva Hecktheuer \\ Fabienne Antunes Ferreira \\ Ricardo Ruiz Mazzon * \\ Laboratório de Genética Molecular de Bactérias \\ Departamento de Microbiologia, Imunologia e Parasitologia \\ Centro de Ciências Biológicas, Universidade Federal de Santa Catarina \\ Campus Universitário Reitor João David Ferreira Lima, CEP 88.040-960, Florianópolis - SC, Brasil \\ * Autor para correspondência \\ ricardo.mazzon@ufsc.br
}

Submetido em 12/07/2021

Aceito para publicação em $28 / 10 / 2021$

\section{Resumo}

Situação epidemiológica da leptospirose no Brasil e desafios em seu diagnóstico. Leptospira interrogans é uma das bactérias causadoras da leptospirose, uma zoonose de ampla distribuição mundial. Atualmente, essa zoonose é considerada uma das que apresenta maiores taxas de morbidade e mortalidade no Brasil (mesmo considerando a Dengue, a maior arbovirose em humanos), com cerca de 3.800 casos humanos por ano documentados. Porém, devido às dificuldades impostas pela ausência de um ensaio de diagnóstico rápido, sensível e que possa ser empregado como teste de rotina para a detecção da leptospirose, essa doença é comumente subnotificada e diagnosticada erroneamente. O teste diagnóstico padrão ouro para a leptospirose é a aglutinação microscópica, o qual apresenta dificuldade de execução e interpretação. Dessa forma, propomos nesta revisão uma visão geral da situação epidemiológica da doença no Brasil, além das contribuições presentes na literatura para o desenvolvimento de novas abordagens diagnósticas. Dentre elas, a análise de polimorfismos de sequências gênicas a qual apresenta potencial para análises filogenéticas, populacionais e de genotipagem de Leptospira spp.

Palavras-chave: Leptospira; MLST; Zoonose

\section{Abstract}

Leptospira interrogans is one of the causative agents of human leptospirosis, a zoonotic disease with worldwide distribution. Nowadays, this zoonosis is considered one of the biggest in terms of morbidity and mortality (even considering Dengue, the major arbovirosis affecting humans), having in Brazil 3,800 human cases per year. Currently, difficulties imposed by the absence of a rapid, sensitive diagnostic test that can be used as a routine test for the detection of leptospirosis lead to misdiagnosis and underreported cases. The gold standard diagnostic test for leptospirosis is the microscopic agglutination test (MAT), which presents difficulties 
in execution and interpretation. Therefore, this review proposes a general view of the epidemiologic situation of the disease in Brazil, in addition to the current contributions in the literature for the development of new diagnostic methods. Amongst them, the gene sequences polymorphism analysis, which presents potential for phylogenetic and populational analysis and genotyping of Leptospira spp.

Key words: Leptospira; MLST; Zoonosis

\section{Introduction}

\section{Leptospira and leptospirosis}

Leptospirosis is a neglected zoonosis worldwide, caused by pathogenic spirochetes of the genus Leptospira, which is associated with the disease in humans or other mammals (LEVETT, 2015). The genus Leptospira includes 64 species, among pathogenic and saprophytic members (VINCENT et al., 2019). Pathogenic Leptospira spp. colonize the proximal renal tubules of the host, and then they are excreted to the environment through the urine, contaminating soil and water samples (KO et al., 2009). The host infection occurs indirectly by touching contaminated material or directly by contact with contaminated urine. Besides colonizing the kidneys, pathogenic leptospires can injure other organs, like the liver and lungs (ADLER; MOCTEZUMA, 2010).

Leptospirosis can occur from an asymptomatic form or mild flu symptoms to a severe clinical condition, known as Weil's disease (KO et al., 2009). This disease usually has a biphasic presentation, characterized by a septicemic acute stage, that persists for around one week, followed by an immune stage, which is defined by the production of antibodies and the end of the symptoms (convalescent phase). If not treated, leptospirosis can progress to its more severe form which, alongside the symptoms aforementioned, may develop kidney and liver failure, and pulmonary hemorrhage (HAAKE; LEVETT, 2015).

In the tropical regions, leptospirosis was estimated to cause 10 or more annual cases per 100,000 population (WHO, 2018). The World Health Organization's Leptospirosis Burden Epidemiology Group estimated that there are 1.03 million of leptospirosis cases per year worldwide, resulting in 58,900 deaths. Such numbers turn leptospirosis the leading zoonotic in terms of morbidity and mortality (COSTA et al., 2015) resulting in approximately 2.9 million disability-adjusted life years (DALY) annually (TORGERSON et al., 2015).

Leptospirosis has a high prevalence in the tropics, where its transmission is favored due to the prolonged survival of the pathogenic leptospires in warm and humid environments (HARTSKEERL et al., 2011). The disease is usually seasonal, presenting increased peak incidence during the rainy season (LEHMANN et al., 2014).

Aside from the rise of pluviometric precipitation values in some seasons of the year, the natural disasters, especially the ones with hydrologic focus, were already related in Brazil as public health emergencies. In the long term, the human population and other animals can be affected by transmissible diseases, like leptospirosis, in an intermediate time span (days and weeks) after disasters. Therefore it's necessary an approach to effectively reducing risk to health associated with disasters (REVISTA DO CENTRO BRASILEIRO DE ESTUDOS DE SAÚDE, 2014; FERENTZ et al., 2021).

In the context of One Health, non-human animals (e.g. dogs) may be great sentinels in the detection of leptospirosis presence in the environment, for also having an important role in the transmission of the disease to humans (GHNEIM et al., 2007). As an example, there is a reported case of a dog which was rescued from the city of Brumadinho, Minas Gerais, after the rupture of the barricade of iron ore waste and exposed to the serovar Copenhageni, of the Icterohaemorrhagiae serogroup, showing a MAT titre $\geq 400$. Thus, it reinforces the importance of the follow-through of cases and diagnosis of non-human leptospirosis for the control of new leptospirosis outbreaks (SILVESTRINI et al., 2020).

The diagnosis of leptospirosis requires compulsory notification since the year 2000 in Brazil (BRASIL, 2017). From that milestone until 2015, the country documented approximately 3,800 leptospirosis cases 
annually. Additionally, the incident rate was 1.9 cases per 100,000 population in both rural and urban areas, (GALAN et al., 2021). However, regional differences were observed, since the south region of Brazil usually has the highest absolute number of cases of leptospirosis in the country (MARTELI et al., 2020). In this region, 16,016 confirmed cases (2007-2019) were reported, where most cases $(6,485$ cases $)$ were registered in the State of Santa Catarina (DATASUS, 2021). Figure 1 shows a comparison of the confirmed cases of human leptospirosis among the Brazilian regions per year, where the South and Southeast regions present the highest number of cases in most years (From the 12 years taken into account, the South region leads for 6 years, and the Southeast region leads for 5 years). Additionally, Figure 2 displays the distribution of leptospirosis cases per 100,000 inhabitants per year among states of the South region of the country. Santa Catarina leads the number of cases in all the documented years. Nevertheless, the human cases of leptospirosis are usually underreported, having a real incidence higher than the ones registered. This underreporting is mainly associated with the challenges to recognize this disease, which will be discussed in the following parts of this review (SILVA, 2017).

FIGURE 1: Leptospirosis cases per region of Brazil from 2007 to 2019.

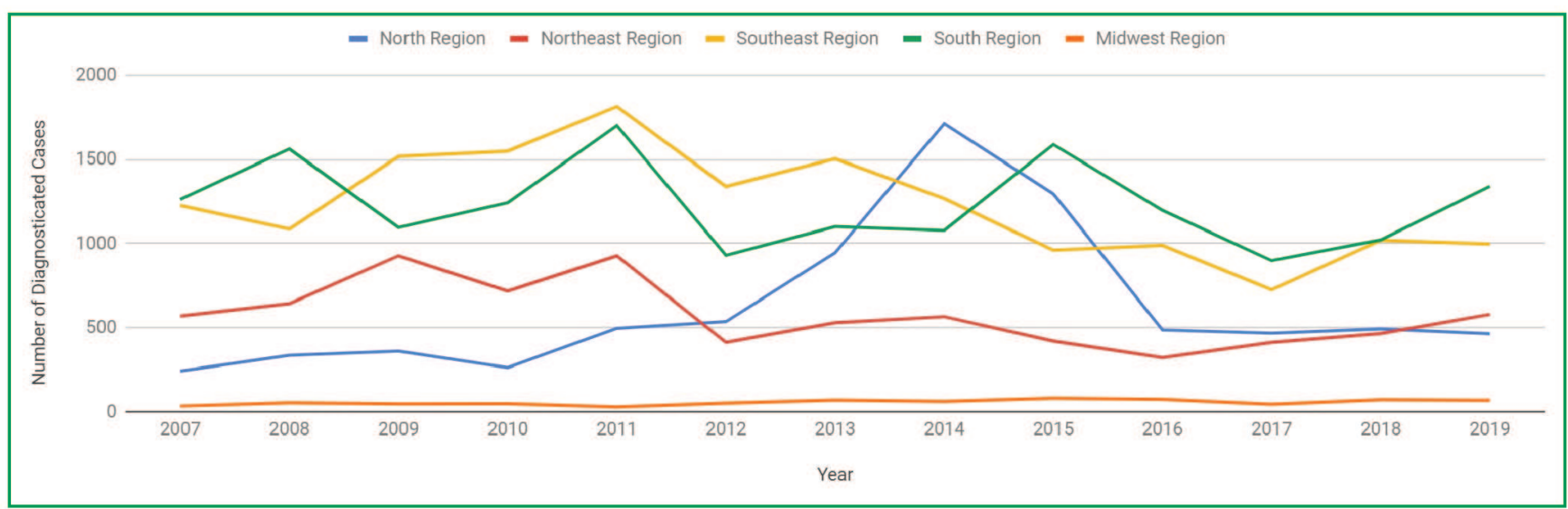

Source: DATASUS (2021).

FIGURE 2: Leptospirosis cases per state of the south region of Brazil from 2007 to 2019.

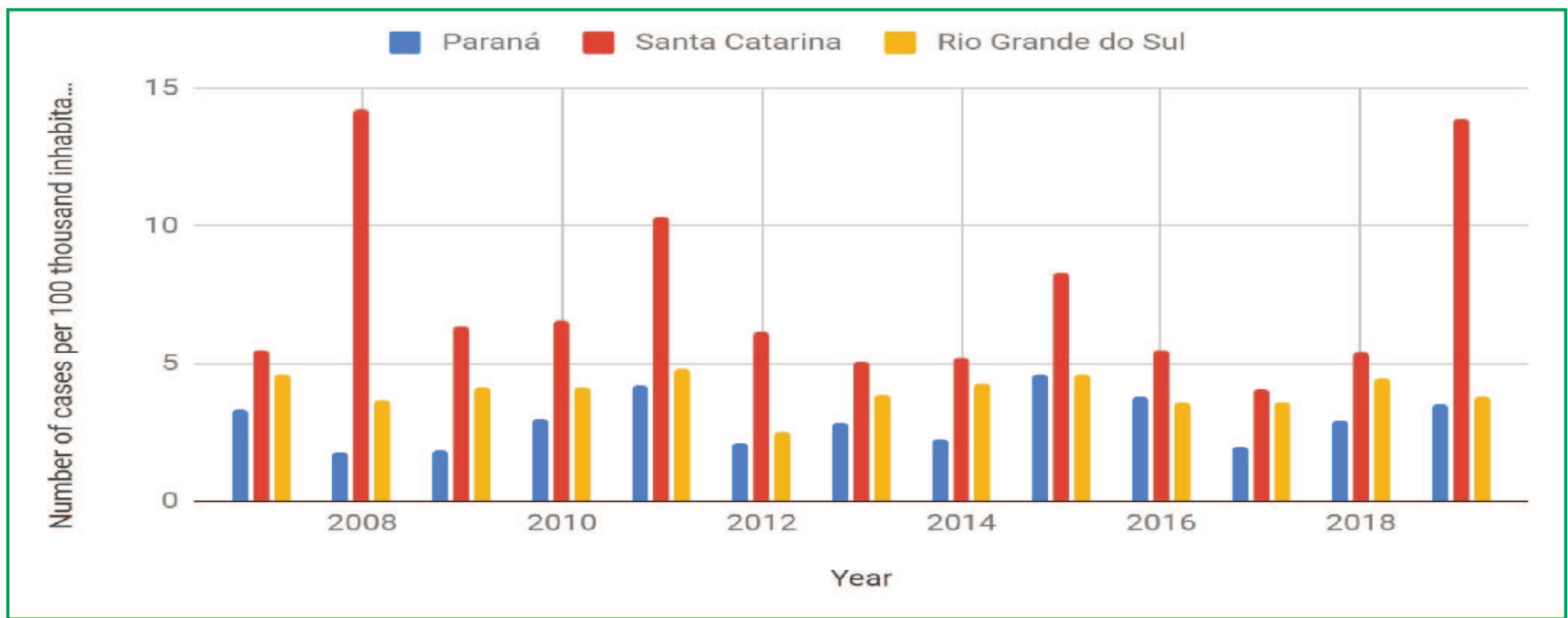

Source: DATASUS (2021). 


\section{Serological and molecular detection of leptospirosis}

Leptospirosis is a febrile disease that can be clinically indistinguishable from other febrile illnesses and arboviruses, leading to delayed or missed diagnosis. Additionally, the laboratory diagnosis is also a particular challenge, since the current commercial tests available are not accurate and easy to interpret (MCBRIDE et al., 2005). Therefore, the development of new diagnosis strategies for this disease are needed in order to improve the detection and epidemiological surveillance of leptospirosis.

Leptospires are bacteria with spiral morphology, highly mobile and thin $(0.1 \mu \mathrm{m} \times 6-20 \mu \mathrm{m})$. In the microorganism's extremities, there are two periplasmic flagella that propel them. It also has in one or in both extremities, a curvature in hook shape. The cell envelope of leptospires is composed of two membranes as expected for gram-negative bacteria, with the external membrane having its external layer made by LPS, as well as with a periplasmic space with thin a layer of peptidoglycans closer to the intern membrane, and the inner cytoplasmic membrane (ADLER; MOCTEZUMA, 2010). According to Figure 3, because of this bilayer structure it's possible to find proteins that are anchored to the internal or external membrane, as well as those running through the periplasmic space, through both membranes. It's believed that proteins exposed to the surface and that have high conservation rates among species of the Leptospira taxa result in a higher production of antibodies, in this way being considered potential targets for vaccines and diagnosis (GRASSMANN et al., 2017).

Over the years, efforts have been made to develop diagnosis tests capable of identifying the presence of antigen or antibodies in both acute (usually in hospital environment) and convalescent phases of the disease. Diagnosis tests should not be evaluated only in terms of specificity or sensibility but should include additional characteristics like the possibility to be executed in space and resource-limited settings (since leptospirosis occur mainly in developing countries); the ease of interpretation of the results, and also the possibility to be portable and relatively stable to environment variations, thus enabling the diagnosis of leptospirosis locally (MUSSO; LA SCOLA, 2013; PICARDEAU et al., 2014).

Diagnosis approaches can be divided in three main groups: microbiological, serological and molecular diagnosis. Among the serological methods (Table 1), the gold standard for leptospirosis is the Microscopic

FIGURE 3: Scheme representing the cell membrane of Leptospira spp. and its membrane proteins. Made with BioRend.

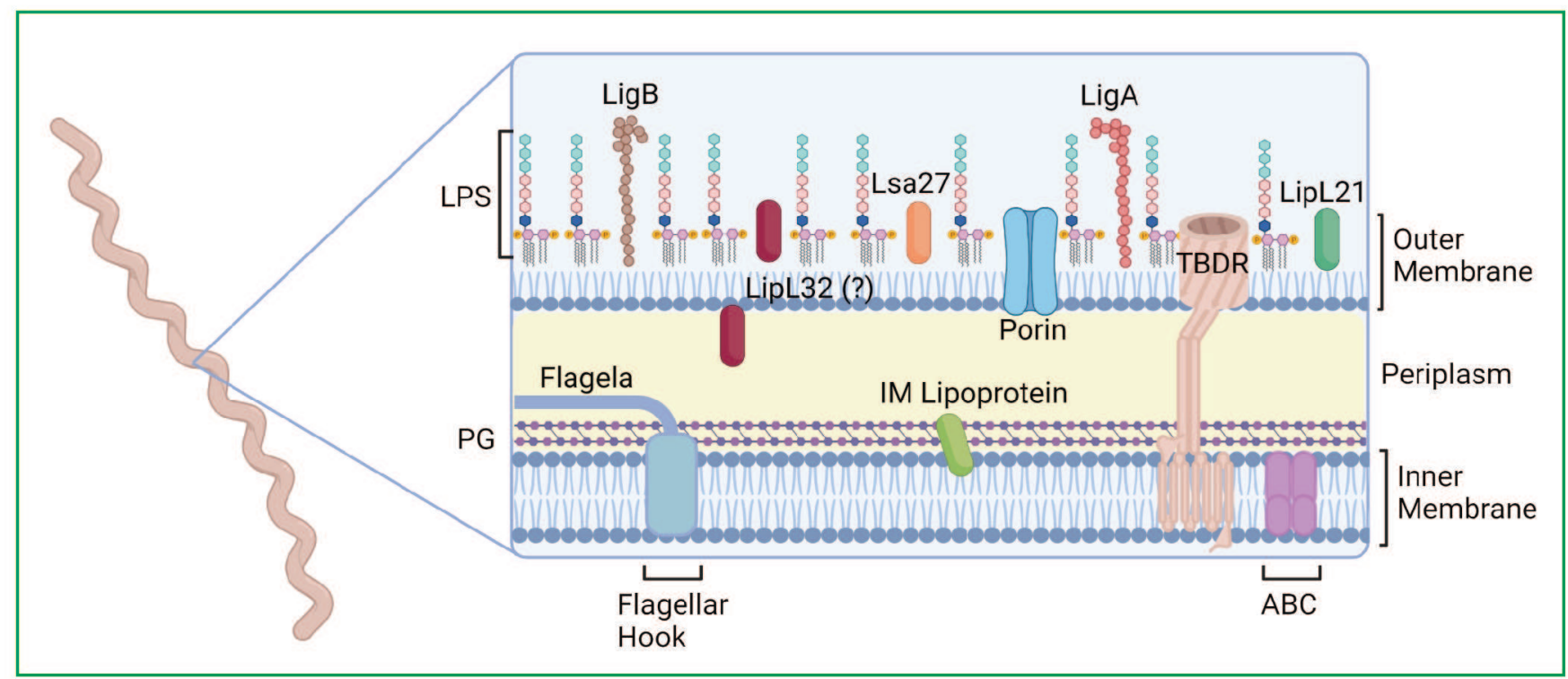

Source: Authors. 
Agglutination Technique (MAT) or Martin and Pettit test (MARTIN; PETTIT, 1918). The MAT is based on the agglutination of the serological samples of the patient when confronted with antigens in suspensions of at least 18 alive leptospires from different serovars (serogroups) (WHO, 2003). However, MAT presents some limitations since (i) cultivation of leptospires is laborious and time-consuming due to the fastidious characteristic of the bacteria, which can result in frequent contaminations; (ii) high cost of available culture media and (iii) the interpretation of the result is subjective (50\% of agglutination) (LIMMATHUROTSAKUL et al., 2012).

Other serological methods like latex agglutination, lateral flow, and Enzyme-Linked Immunosorbent Assay (ELISA) may circumvent those limitations. Rapid assays for specific antibody detection can be executed immediately after the collection of the biological sample, allowing for a quick diagnosis and early drug intervention, improving the treatment and prognosis of the patient. Additionally, ELISA is considered more sensitive when compared to MAT to the detection of Immunoglobulin $M$ (IgM) during the acute phase of the disease in humans (RIBEIRO et al., 1995). On the other hand, the fact that the disease has a biphasic form (acute and convalescent phases) is a limitation to serological tests, since the antibodies in the acute phase are detected only around 4 to 5 days after the infection (PICARDEAU, 2013).

The application of molecular techniques for leptospirosis diagnosis is currently an important alternative (Table 2) (GUNASEGAR; NEELA, 2021). Tests based on the amplification of DNA segments like PCR (Polymerase Chain Reaction) are among the most efficient to confirm the diagnosis. However, this method requires technical knowledge to be executed, and it presents a high-cost in equipment and reagents, which can limit the implementation in resource-limited settings without specific competence in the field. (WAGGONER; PINSKY, 2016). Variations in the traditional PCR method like Nested PCR, PCR Multiplex, and LoopMediated Isothermal Amplification (LAMP) have been studied and can be applied to diagnosis with variable cost, sensibility and specificity.
Although some diagnostic techniques are commercially available for leptospirosis, new and improved methods are still required to increase the power of the diagnosis and diminish the underreport of the disease. Ideally, methods must be sensible and specific enough to detect the infection in different phases of the disease and to be affordable to be available for resource-limited settings.

The criteria used for the selection of the papers were: studies in Portuguese or English, that contemplates the leptospirosis and diagnosis relationship, which means that both subjects were addressed together in the study. For each paper selected, it was analyzed the title, abstract, keywords, and results. After this first analysis, the papers that corresponded to the proposed criteria were separated by year, the technique utilized, and main results. Such information was categorized and distributed together with the pros and cons of each diagnostic approach.

\section{Development of a Multilocus Sequence Typing (MLST) scheme for Leptospira spp.}

Genotyping is a process to analyze single strains of bacteria at the genomic level (based on the DNA sequences). It is important to reliably differentiate among related bacterial isolates of the same species, which is essential for epidemiological surveillance, detection of the sources of outbreaks and to study bacterial population and transmission dynamics (VAN BELKUM et al., 2007; WOLSKA; SZWEDA, 2012). Therefore, genotyping methods are critical to the understanding of the dynamic of Leptospira in the environment and in the different hosts. Among the main techniques that have been employed to genotype Leptospira strains, Amplified fragment length polymorphism (AFLP) (VIJAYACHARI et al., 2004), Multilocus Variable Number of Tandem Repeat Analysis (MLVA) (MAJED et al., 2005), and Pulsed-Field Gel Electrophoresis (PFGE) (GALLOWAY; LEVETT, 2010) are the most studied. Currently, AFLP and PFGE present limited discriminatory power and low reproducibility for certain groups of strains, while the MLVA presents the disadvantage of being accurate only for strains of $L$. 
TABLE 1: Serological diagnostic methods for leptospirosis based on the identification of Immunoglobulin M (IgM) and/or Immunoglobulin $\mathrm{G}(\operatorname{IgG})$, including the pros and cons.

\begin{tabular}{|c|c|c|c|c|}
\hline Method & Target & Pros & Cons & Sources \\
\hline \multirow{5}{*}{ ELISA } & IgM & \multirow{5}{*}{$\begin{array}{l}\text { IgM antibodies can be detected } \\
\text { in the first week of the disease. } \\
\text { During the elapse of the disease, } \\
\text { the levels of IgG become higher, } \\
\text { evidencing the convalescent } \\
\text { phase of leptospirosis. }\end{array}$} & \multirow{5}{*}{$\begin{array}{l}\text { Variable Specificity and sensibility. } \\
\text { An epidemiologic study of the } \\
\text { strains present in the region may } \\
\text { be needed. }\end{array}$} & \multirow{5}{*}{$\begin{array}{c}\text { Aihua et al. } \\
\text { (2011) } \\
\text { Vedhagiri et al. } \\
\text { (2013) } \\
\text { Martinez et al. } \\
\text { (2021) }\end{array}$} \\
\hline & $\begin{array}{c}\operatorname{IgG} \\
\operatorname{IgM}-\operatorname{IgG}\end{array}$ & & & \\
\hline & LipL32-specific & & & \\
\hline & $\operatorname{IgM}$ & & & \\
\hline & $\begin{array}{c}\text { rLipL32/1- } \\
\text { LipL21- } \\
\text { OmpL1/2- IgM }\end{array}$ & & & \\
\hline
\end{tabular}

$\begin{array}{ccc}\text { Latex } & \begin{array}{c}\text { Diagnosis screening test, simple, } \\ \text { fast and highly sensitive and } \\ \text { agglutination } \\ \text { specific. } \\ \text { LigB protein }\end{array} & \begin{array}{c}\text { High stability to transportation } \\ \text { and prolonged storage (long } \\ \text { shelf life). }\end{array}\end{array}$

Hull-Jackson et al.

(2006)

May present weak results in the acute phase of the disease, since the antibody level is low.

Shekatkar et al.

Nagalingam et al. (2015)

Alamuri et al. (2020)

\begin{tabular}{c}
$\begin{array}{c}\text { Lateral flow } \\
\text { immunoassay } \\
\text { rapid test }\end{array} \quad \operatorname{IgM} \quad \begin{array}{c}\text { Alternative as a screening test, } \\
\text { especially in places where MAT } \\
\text { is not available, like farms, } \\
\text { hospitals and remote areas. }\end{array}$ \\
\hline
\end{tabular}

Gold standard for the

MAT IgG e IgM diagnosis of human and animal leptospirosis.
Rao et al.

results by other methodology.

Higher specificity than sensibility.

Amran et al. (2018)

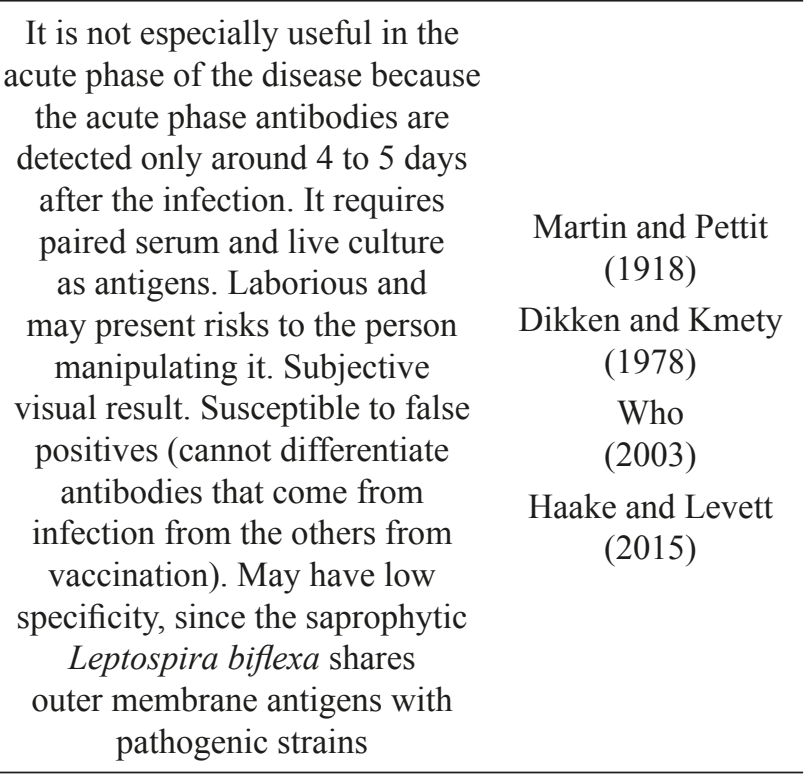

Source: Authors. 
TABLE 2: Comparison of the molecular diagnostic methods based in the Polymerase Chain Reaction (PCR) for leptospirosis, including its pros and cons.

\begin{tabular}{|c|c|c|c|c|}
\hline Method & Target & Pros & Cons & Sources \\
\hline PCR & $\begin{array}{l}\operatorname{lipL32} \\
\quad r r s \\
\sec Y \\
16 \mathrm{~S} r D N A\end{array}$ & $\begin{array}{l}\text { Allows the identification of } \\
\text { pathogenic species, as well as } \\
\text { environmental surveillance. } \\
\text { Faster and simpler than culture/ } \\
\text { MAT. Allows detection in the } \\
\text { earlier stages of infection. } \\
\text { This method can be used even } \\
\text { in patients that have initiated } \\
\text { antibiotics use. }\end{array}$ & $\begin{array}{l}\text { High cost of } \\
\text { equipment and } \\
\text { reagents, and technical } \\
\text { competence. }\end{array}$ & $\begin{array}{l}\text { Romero et al. (2010) } \\
\text { Blanco and Romero (2014) } \\
\text { Vanasco et al. (2016) } \\
\text { Nagalingam et al. (2015) } \\
\text { Podgoršek et al. (2020) } \\
\text { Philip et al. (2020a) }\end{array}$ \\
\hline $\begin{array}{c}\text { qPCR } \\
\text { (Real Time } \\
\text { Quantitative PCR) }\end{array}$ & $\begin{array}{l}\sec Y \\
r r s \\
\text { lipL32 } \\
\text { flaB }\end{array}$ & $\begin{array}{l}\text { Removal of the step of } \\
\text { electrophoresis in agarose gel. } \\
\text { Precise quantification. Higher } \\
\text { sensibility in comparison to } \\
\text { conventional PCR. }\end{array}$ & $\begin{array}{l}\text { High cost for } \\
\text { small laboratories/ } \\
\text { settings, especially in } \\
\text { developing countries, } \\
\text { where this disease is } \\
\text { predominant. }\end{array}$ & $\begin{array}{c}\text { Ahmed et al. (2009) } \\
\text { Waggoner et al. (2014) } \\
\text { Denipitiya et al. (2016) } \\
\text { Ali et al. (2018) } \\
\text { Iwasaki et al. (2016) } \\
\text { Shukla et al. (2021) }\end{array}$ \\
\hline $\begin{array}{l}\text { qRT-PCR (Real-Time } \\
\text { Quantitative Reverse } \\
\text { Transcription PCR) }\end{array}$ & $\begin{array}{c}\operatorname{rrs}(16 \mathrm{~S} \\
\text { rRNA) }\end{array}$ & $\begin{array}{l}\text { More sensibility than the } \\
\text { corresponding assays of } \\
\text { quantitative PCR (qPCR). }\end{array}$ & $\begin{array}{l}\text { It requires RNA } \\
\text { extraction and cDNA } \\
\text { synthesis, increasing } \\
\text { the cost and time }\end{array}$ & Backstedt et al. (2015) \\
\hline PCR Multiplex & $\begin{array}{c}\operatorname{lipL32} \\
16 \mathrm{~s} \text { rRNA }\end{array}$ & $\begin{array}{l}\text { Higher specificity over } \\
\text { conventional PCR, due to the } \\
\text { detection of a higher number } \\
\text { of genes. Multiple fragments } \\
\text { amplified simultaneously. }\end{array}$ & $\begin{array}{l}\text { Chance of nonspecific } \\
\text { binding between } \\
\text { the oligonucleotides } \\
\text { leading to false } \\
\text { positives. }\end{array}$ & $\begin{array}{l}\text { Ahmed et al. (2012) } \\
\text { Philip et al. (2020b) }\end{array}$ \\
\hline Nested PCR & $\begin{array}{l}\operatorname{lip} L 32 \\
\text { ompL1 } \\
\text { 16S rRNA } \\
\quad \text { flaB }\end{array}$ & $\begin{array}{l}\text { Higher sensibility in comparison } \\
\text { to conventional PCR. Primers } \\
\text { have a lower chance of } \\
\text { annealing in nonspecific } \\
\text { sequences, because of the size } \\
\text { reduction of the amplicon. }\end{array}$ & $\begin{array}{l}\text { Risk of contamination. } \\
\text { More time- and } \\
\text { resources- consuming } \\
\text { when compared to the } \\
\text { conventional PCR. }\end{array}$ & $\begin{array}{l}\text { Boonsilp et al. (2011) } \\
\text { Koizumi et al. (2012) } \\
\text { Bandara et al. (2016) } \\
\text { Hsu et al. (2017) }\end{array}$ \\
\hline LAMP - PCR & $\begin{array}{l}\text { rrs } \\
\text { lipl32 } \\
\text { lipl21 } \\
\text { flab } \\
\text { lipL41 }\end{array}$ & $\begin{array}{l}\text { Better diagnostic accuracy } \\
\text { of Leptospira species than } \\
\text { traditional PCR. No need of } \\
\text { thermocycler, electrophoresis } \\
\text { and transilluminator. Faster } \\
\text { results over other molecular } \\
\text { methodologies. Results can be } \\
\text { measured by real-time } \\
\text { turbidity method. }\end{array}$ & $\begin{array}{l}\text { Due to its high } \\
\text { amplification } \\
\text { efficiency, the } \\
\text { LAMP reaction } \\
\text { has higher chances } \\
\text { of a false-positive } \\
\text { amplification caused } \\
\text { by contamination by } \\
\text { transference. Higher- } \\
\text { throughput primer } \\
\text { design. }\end{array}$ & $\begin{array}{l}\text { Sengupta et al. (2017) } \\
\text { Tubalinal et al. (2018) } \\
\text { Najian et al. (2019) } \\
\text { Monica et al. (2019) }\end{array}$ \\
\hline
\end{tabular}

Source: Authors. 
interrogans. Therefore, MLST (Multilocus Sequence Typing) has been suggested as an important alternative to genotyping Leptospira (AHMED et al., 2006; BOONSILP et al., 2013; VARNI et al., 2014).

MLST allows to gather more accurate clinical data that permits better studies about this genus virulence, and epidemiologic surveillance, that allows to detect outbreaks and the dynamic of transmission among hosts.

MLST is a genotyping method based on the sequencing of single-nucleotide polymorphisms (SNPs) of housekeeping genes or essential genes, with each PCR fragment named as a distinct allele. From the upload of the set of alleles of the selected genes, the sequence typing (ST) is determined. Therefore, isolates with the same allelic profile (or the same ST) are described as being part of the same clone. The first MLST scheme was described at the end of the 1990s for Neisseria meningitidis and it is largely employed nowadays as a typing method for many bacterial species (MAIDEN et al., 1998; 2013).

The MLST method usually presents higher resolution and higher replicability when compared to other traditional typing methods. Additionally, to find the corresponding ST, MLST requires the submission of the sequencing of the housekeeping genes in online databases, making the results available through a collaborative network. On the other hand, variability of housekeeping genes among bacteria strains still presents itself as a bottleneck for the development of MLST schemes for certain species (MAIDEN et al., 2013).
Currently, there are 3 MLST schemes available for Leptospira spp. that can be accessed through the following website link <https://pubmlst.org/organisms/ leptospira-spp/> (JOLLEY et al., 2018). During the selection of a gene for a MLST scheme, it's important that the gene presents a slow evolution among the same species (AHMED et al., 2006). Therefore, the main genes used in the available MLST schemes for Leptospira spp. are usually genes encoding outer membrane proteins, 16S rRNA and housekeeping genes (Table 3).

Boonsilp et al. (2013) reported that even with the small number of samples of Leptospira submitted to the MLST scheme it was possible to assign the samples to distinct clades with $100 \%$ of precision, suggesting the potential for global epidemiological survey, including the main pathogenic species in the Leptospira genus. This same study also demonstrated a potential for this approach in defining the species' phylogeography through time and linking the species to their maintenance hosts (BOONSILP et al., 2013).

Another positive point of the MLST method is the possibility of tracing the transmission pathways of clones between maintenance and incidental hosts from the genetic diversity among strains and in the same species (BOONSILP et al., 2013). However, none of those MLST methods allows the inclusion of all the main strains of Leptospira, including saprophytic strains. In the last 10 years, several Leptospira genomes have been sequenced, facilitating the design of new primers for an improved or new MLST scheme that may cover

TABLE 3: Schemes of genes amplified in the MLST assay for Leptospira spp available in the PubMLST database (JOLLEY et al., 2018).

\begin{tabular}{|c|c|c|}
\hline MLST Scheme & Characterization and species assignment & Authors \\
\hline $\begin{array}{c}g l m U, \\
\text { pntA, sucA, } t \text { tpiA, pfkB, mreA, } \\
\text { caiB }\end{array}$ & $\begin{array}{c}\text { L. interrogans, L. borgpetersenii, L. alexanderi, } L . \\
\text { kirschneri, L. noguchii, L. } \\
\text { santarosai and L. weilii }\end{array}$ & Boonsilp et al. (2013) \\
\hline $\begin{array}{l}\text { adk, glmU, icdA, lipL32, } \\
\text { lipL41, mreA е pntA }\end{array}$ & L. interrogans and L. kirschneri & Varni et al. (2014) \\
\hline $\begin{array}{c}a d k, \text { icdA, lipL32, lipL41, } \\
\text { rrs2 e secY }\end{array}$ & L. interrogans and L. kirschneri & Ahmed et al. (2006) \\
\hline
\end{tabular}

Source: Authors. 
all clades of Leptospira, since the most recent scheme was described in 2014.

The analysis of the genes encoding the 16s rRNA is largely employed for phylogenetic and typing studies, since those sequences are less susceptible to horizontal gene transfer and variations along evolution (ACINAS et al., 2004). The precision of the phylogenetic analysis based on 16S rRNA usually decreases among specific species or among the serovar of Leptospira (TAN et al., 2013), requiring other gene markers to better solve those taxa. Furthermore, the analysis of $16 \mathrm{~S}$ rRNA can be challenging when working with certain taxonomic groups, since many bacteria have multiple copies of those sequences in the genome (ACINAS et al., 2004).

Despite the efforts, the scheme presenting the best discriminatory power among the species of the genus was the one described from Boonsilp et al. (2013), which can be used for seven species, whoever Leptospira is a genus with 64 species in four sub-clades, therefore new schemes with a better discriminatory power are needed to avoid false negatives.

For this reason, recent studies propose the analysis of complete genome sequences called core genome multilocus sequence typing (cgMLST) as an efficient, accurate and reproducible method for genotyping of Leptospira isolates. In contrast to MLST, the cgMLST analyses hundreds of loci for the comparison of genes of the assembled genome, allowing the identification of species, clades, clonal groups, and sequence types, turning this method one of the most straightforward ways to explore complex genomic data in an epidemiological context (GUGLIELMINI et al., 2019; GRILLOVÁ; PICARDEAU, 2020). Guglielmini et al. (2019) contributed to the collection of scientific data to the development of a cgMLST scheme from comparative analysis using Leptospira strains for many sources and geographic locations, by identifying 764 core genes for the genus, being 545 of those considered suitable for cgMLST genotyping (GUGLIELMINI et al., 2019).

\section{Closing remarks}

The unspecific clinical symptoms of leptospirosis and the diversity among the species of the Leptospira genus led to limitations in the clinical and laboratory diagnosis, often causing the zoonosis to be underreported. Due to these challenges, many studies have been developed to identify novel diagnostic targets capable of inclusion and classification at serovar level. The cost per test and facility structure are of extreme importance when developing a leptospirosis diagnostic method, since outbreaks of this disease are more frequent in developing countries, which commonly present limited resources. It is important to notice that rapid methods need to consider rural areas and cities located away from the certificated laboratories, allowing local diagnosis. Studies to improve the sensibility and specificity rates of the diagnostic tests are also required.

The availability of genotypic analysis though online databases, like PubMLST, opens the door for sharing data among groups of various locations, supporting epidemiological data on local, global, and long-term scales. Currently, the cgMLST may represent a promising scheme for the genotyping of Leptospira isolates and offers an opportunity to better understand those Spirochaetes, since cgMLST can be performed to study transmission among hosts and detection and surveillance of outbreaks.

\section{Acknowledgements}

This study was financed in part by the Coordenação de Aperfeiçoamento de Pessoal de Nível Superior Brasil (CAPES) - Finance Code 001 and National Council for Scientific and Technological Development (CNPq). To Professor Gislaine Fongaro for the assistance on the image creation.

\section{References}

ACINAS, S. G.; MARCELINO, L. A.; KLEPAC-CERAJ, V.; POLZ, M. F. Divergence and redundancy of $16 \mathrm{~S}$ rRNA sequences in genomes with multiple rrn operons. Journal of Bacteriology, Washington, v. 186, n. 9, p. 2629-2635, 2004.

ADLER, B.; MOCTEZUMA, A. de la P. Leptospira and leptospirosis. Veterinary Microbiology, Geneve, v. 140, n. 3-4, p. 287-296, 2010.

AHMED, M. F. M.; ENGELBERTS, K. R.; BOER, N. A.; HARTSKEER, R. A. Development and validation of a real-time PCR for detection of pathogenic Leptospira species in clinical materials. PloS One, Cambridge, v. 4, n. 9, p. e7093, 2009. 
AHMED, N.; DEVI, S. M.; VALVERDE, M. de los A.; VIJAYACHARI, P.; MACHANG'U, R. S.; ELLIS, W. A.; HARTSKEER, R. A. Multilocus sequence typing method for identification and genotypic classification of pathogenic Leptospira species. Annals of Clinical Microbiology and Antimicrobials, London, v. 5, n. 1, p. 1-10, 2006.

AHMED, S. A.; SANDAI, D. A.; MUSA, S.; HOE, C. H.; RIADZI, M.; LAU, K. L.; TANG, T. H. Rapid diagnosis of leptospirosis by multiplex PCR. The Malaysian Journal of Medical Sciences, Pulau Pinang, v. 19, n. 3, p. 9, 2012.

AIHUA, S. U. N.; WANG, Y.; DU, P.; WU, S.-H.; YAN, J. A sensitive and specific IgM-ELISA for the serological diagnosis of human leptospirosis using a rLipL32/1-LipL21-OmpL1/2 fusion protein. Biomedical and Environmental Sciences, Beijing, v. 24, n. 3, p. 291-299, 2011.

ALAMURI, A.; VINOD KUMAR, K.; SOWJANYAKUMARI, S.; LINSHAMOL, L.; SRIDEVI, R.; NAGALINGAM, M.; ROY, P.; BALAMURUGAN, V. Expression of recombinant Leptospiral Surface Lipoprotein-Lsa27 in E. coli and its evaluation for serodiagnosis of bovine leptospirosis by Latex Agglutination Test. Molecular Biotechnology, Oklahoma City, v. 62, n. 11, p. 598$610,2020$.

ALI, M. R. M.; SAFEE, A. W. M.; ISMAIL, N. H.; SAPIAN, R. A. H.; HUSSIN, H. M.; ISMAIL, N.; YEAN, C. Y. Development and validation of pan-Leptospira Taqman qPCR for the detection of Leptospira spp. in clinical specimens. Molecular and Cellular Probes, Amsterdam, v. 38, p. 1-6, 2018.

AMRAN, F.; LIOW, Y. L.; HALIM, N. A. N. Evaluation of a commercial immuno-chromatographic assay kit for rapid detection of IgM antibodies against Leptospira antigen in human serum. Journal of Korean Medical Science, Seoul, v. 33, n. 17, p. 1-6, 2018 .

BACKSTEDT, B. T.; BUYUKTANIR, O.; LINDOW, J.; WUNDER JR., E. A.; REIS, M. G.; USMANI-BROWN, S.; LEDIZET, M.; $\mathrm{KO}$, A.; PAL, U. Efficient detection of pathogenic leptospires using 16S ribosomal RNA. PLoS One, Cambridge, v. 10, n. 6, p. e0128913, 2015.

BANDARA, K.; WEERASEKERA, M. M.; GUNASEKARA, C.; RANASINGHE, N.; MARASINGHE, C.; FERNANDO, N. Utility of modified Faine's criteria in diagnosis of leptospirosis. BMC Infectious Diseases, London, v. 16, n. 1, p. 1-7, 2016.

BLANCO, R. M.; ROMERO, E. C. Evaluation of nested polymerase chain reaction for the early detection of Leptospira spp. DNA in serum samples from patients with leptospirosis. Diagnostic Microbiology and Infectious Disease, Stanford, v. 78, n. 4, p. 343346, 2014.

BOONSILP, S.; THAIPADUNGPANIT, J.; AMORNCHAI, P.; WUTHIEKANUN, V.; BAILEY, M. S.; HOLDEN, M. T. G.; ZHANG, C.; JIANG, X.; KOIZUMI, N.; TAYLOR, K.; GALLOWAY, R.; HOFFMASTER, A. R.; CRAIG, S.; SMYTHE, L. D.; HARTSKEERL, R. A.; DAY, N. P.; CHANTRATITA, N.; FEIL, E. J.; AANENSEN, D. M.; SPRATT, B. G.; PEACOCK, S. J. A single multilocus sequence typing (MLST) scheme for seven pathogenic Leptospira species. Plos Neglected Tropical Diseases, San Francisco, v. 7, n. 1, p. e1954, 2013.

BOONSILP, S.; THAIPADUNGPANIT, J.; AMORNCHAI, P.; WUTHIEKANUN, V.; CHIERAKUL, W.;
LIMMATHUROTSAKUL, D.; DAY, N. P.; PEACOCK, S. J. Molecular detection and speciation of pathogenic Leptospira spp. in blood from patients with culture-negative leptospirosis. BMC Infectious Diseases, London, v. 11, n. 1, p. 1-9, 2011.

BRASIL. Guia de vigilância em saúde. Brasília: CoordenaçãoGeral de Desenvolvimento da Epidemiologia em Serviços. Secretaria de Vigilância em Saúde. Ministério da Saúde. 2017. Disponível em: <https://portalarquivos.saude.gov.br/images/ pdf/2017/outubro/06/Volume-Unico-2017.pdf>.

COSTA, J. E. F.; HAGAN, J. E.; CALCAGNO, J.; KANE, M.; TORGERSON, P.; MARTINEZ-SILVEIRA, M. S.; STEIN, C.; ABELA-RIDDER, B.; KO, A. I. Global morbidity and mortality of leptospirosis: a systematic review. Plos Neglected Tropical Diseases, San Francisco, v. 9, n. 9, p. e0003898, 2015.

DATASUS. Tabnet. Brasília: Ministério da Saúde: Departamento de Informática do SUS. Disponível em: <http://tabnet.datasus.gov. br/cgi/deftohtm.exe?sinannet/cnv/leptobr.def $>$.

DENIPITIYA, D. T. H.; CHANDRASEKHARAN, N. V.; ABEYEWICKREME, W.; HARTSKEERL, C. M.; HARTSKEERL, R. A.; JIFFREY, A. M.; HAPUGODA, M. D. Application of a real time Polymerase Chain Reaction (PCR) assay for the early diagnosis of human leptospirosis in Sri Lanka. Biologicals, London, v. 44, n. 6, p. 497-502, 2016.

DIKKEN, H.; KMETY, E. Chapter VIII serological typing methods of leptospires. In: BERGAN, T.; NORRIS, J. R. (Ed.). Methods in microbiology. New York: Academic Press, 1978. p. 259-307.

FERENTZ, L.; FONSECA, M. N. da; PINHEIRO, E. G.; GARCIAS, C. Use of global instruments for evaluating health disaster resilience. Saúde em Debate, Rio de Janeiro, v. 44, p. 115$131,2021$.

GALAN, D. I.; ROESS, A. A.; PEREIRA, S. V. C.; SCHNEIDER, M. C. Epidemiology of human leptospirosis in urban and rural areas of Brazil, 2000-2015. Plos One, Cambridge, v. 16, n. 3, p. $\mathrm{e} 0247763,2021$.

GALLOWAY, R. L.; LEVETT, P. N. Application and validation of PFGE for serovar identification of Leptospira clinical isolates. PLoS Neglected Tropical Diseases, San Francisco, v. 4, n. 9, p. e824, 2010.

GHNEIM, G. S.; VIERS, J. H.; CHOMEL, B. B.; KASS, P. H.; DESCOLLONGES, D. A.; JOHNSON, M. L. Use of a casecontrol study and geographic information systems to determine environmental and demographic risk factors for canine leptospirosis. Veterinary Research, Onderstepoort, v. 38, n. 1, p. 37-50, 2007.

GRASSMANN, A. A.; SOUZA, J. D.; MCBRIDE, A. J. A. A universal vaccine against leptospirosis: are we going in the right direction? Frontiers in Immunology, Lausanne, v. 8, p. 256, 2017.

GRILlOVÁ, L.; PICARDEAU, M. Core genome multilocus sequence typing analyses of Leptospira spp. using the bacterial isolate genome sequence database. In: KOIZUMI, N.; PICARDEAU, M. (Ed.). Leptospira spp. New York: Humana Press, 2020. p. 11-21.

GUGLIELMINI, J.; BOURHY, P.; SCHIETTEKATTE, O.; ZININI, F.; BRISSE, S.; PICARDEAU, M. Genus-wide Leptospira core genome multilocus sequence typing for strain taxonomy and global surveillance. PLoS Neglected Tropical Diseases, San Francisco, v. 13, n. 4, p. e0007374, 2019. 
GUNASEGAR, S.; NEELA, V. K. Evaluation of diagnostic accuracy of loop-mediated isothermal amplification method (LAMP) compared with polymerase chain reaction (PCR) for Leptospira spp. in clinical samples: a systematic review and metaanalysis. Diagnostic Microbiology and Infectious Disease, Stanford, v. 100, n. 3, p. 115369, 2021.

HAAKE, D. A.; LEVETT, P. N. Leptospirosis in humans. In: ADLER, B. (Ed.). Leptospira and leptospirosis. Berlin/Heidelberg: Springer-Verlag, 2015. p. 65-97.

HARTSKEERL, R. A.; COLLARES-PEREIRA, M.; ELLIS, W. A. Emergence, control and re-emerging leptospirosis: dynamics of infection in the changing world. Clinical Microbiology and Infection, London, v. 17, n. 4, p.494-501, 2011.

HSU, Y.-H.; CHOU, S.-J.; CHANG, C.-C.; PAN, M.-J.; YANG, W.-C.; LIN, C.-F.; CHAN, K.-W. Development and validation of a new loop-mediated isothermal amplification for detection of pathogenic Leptospira species in clinical materials. Journal of Microbiological Methods, Amsterdam, v. 141, p. 55-59, 2017.

HULL-JACKSON, C.; GLASS, M. B.; ARI, M. D.; BRAGG, S. L.; BRANCH, S. L.; WHITTINGTON, C. U.; EDWARDS, C. N.; LEVETT, P. N. Evaluation of a commercial latex agglutination assay for serological diagnosis of leptospirosis. Journal of Clinical Microbiology, Washington, v. 44, n. 5, p. 1853-1855, 2006.

IWASAKI, H.; CHAGAN-YASUTANA, H.; LEANO, P. S. A.; KOIZUMI, N.; NAKAJIMA, C.; TAURUSTIATI, D.; HANAN, F.; LACUESTA, T. L.; ASHINO, Y.; SUZUKI, Y.; GLORIANI, N. G.; TELAN, E. F. O.; HATTORI, T. Combined antibody and DNA detection for early diagnosis of leptospirosis after a disaster. Diagnostic Microbiology and Infectious Disease, Stanford, v. 84, n. 4, p. 287-291, 2016.

JOLLEY, K. A.; BRAY, J. E.; MAIDEN, M. C. J. Open-access bacterial population genomics: BIGSdb software, the PubMLST. org website and their applications. Wellcome Open Research, London, v. 3, p. 1-20, 2018.

KO, A. I.; GOARANT, C.; PICARDEAU, M. Leptospira: the dawn of the molecular genetics era for an emerging zoonotic pathogen. Nature Reviews Microbiology, London, v. 7, n. 10, p. 736-747, 2009.

KOIZUMI, N.; KOIZUMI, N.; NAKAJIMA, C.; HARUNARI, T.; TANIKAWA, T.; TOKIWA, T.; UCHIMURA, E.; FURUYA, T.; MINGALA, C. L.; VILLANUEVA, M. A.; OHNISHI, M.; SUZUKI, Y. A new loop-mediated isothermal amplification method for rapid, simple, and sensitive detection of Leptospira spp. in urine. Journal of Clinical Microbiology, Washington, v. 50, n. 6, p. 2072-2074, 2012.

LEHMANN, J. S.; MATTHIAS, M. A.; VINETZ, J. M.; FOUTS, D. E. Leptospiral Pathogenomics. Pathogens, Basel, v. 3, n. 2, p. 280-308, 2014.

LEVETT, P. N. Systematics of leptospiraceae. In: ADLER, B. (Ed.). Leptospira and leptospirosis. Berlin/Heidelberg: SpringerVerlag, 2015. p. 11-20.

LIMMATHUROTSAKUL, D.; TURNER, E. L.; WUTHIEKANUN, V.; THAIPADUNGPANIT, J.; SUPUTTAMONGKOL, Y.; CHIERAKUL, W.; SMYTHE, L. D.; DAY, N. P. J.; COOPER, B.; PEACOCK, S. J. Fool's gold: why imperfect reference tests are undermining the evaluation of novel diagnostics: a reevaluation of
5 diagnostic tests for leptospirosis. Clinical Infectious Diseases, Oxford, v. 55, n. 3, p. 322-331, 2012.

MAIDEN, M. C. J.; JANSEN VAN RENSBURG, M. J.; BRAY, J. E.; EARLE, S. G.; FORD, S. A.; JOLLEY, K. A.; MCCARTHY, N. D. MLST revisited: the gene-by-gene approach to bacterial genomics. Nature Reviews Microbiology, London, v. 11, n. 10, p. 728-736, 2013.

MAIDEN, M. C. J.; MAIDEN, M. C.; BYGRAVES, J. A.; FEIL, E.; MORELLI, G.; RUSSELL, J. E; URWIN, R.; ZHANG, Q.; ZHOU, J.; ZURTH, K.; CAUGANT, D. A.; FEAVERS, I. M.; ACHTMAN, M.; SPRATT, B. G. Multilocus sequence typing: a portable approach to the identification of clones within populations of pathogenic microorganisms. Proceedings of the National Academy of Sciences of the United States of America, Washington, v. 95, n. 6, p. 3140-3145, 1998.

MAJED, Z.; BELlENGER, E.; POSTIC, D.; POURCEL, C.; BARANTON, G.; PICARDEAU, M. Identification of variablenumber tandem-repeat loci in Leptospira interrogans sensu stricto. Journal of Clinical Microbiology, Washington, v. 43, n. 2, p. 539$545,2005$.

MARTELI, A. N.; GENRO, L. V.; DIAMENT, D.; GUASSELLI, L. A. Spatial analysis of leptospirosis in Brazil. Saúde em Debate, Rio de Janeiro, v. 44, n. 126, p. 805-817, 2020.

MARTIN, L.; PETTIT, A. Sero-diagnostic de la spirochaetose icterohaemorrhagique. Bulletins et Mémoires de la Société Médicale des Hôpitaux de Paris, Paris, v. 42, p. 672-675, 1918.

MARTINEZ, M. L.; RODRIGUEZ, M. A.; IRAZU, L. E.; ROMERO, G. N.; SARAULLO, V. R.; WATANABE, O.; HAMER, M.; LOFFLER, S. G.; SAMARTINO, L. E.; BRIHUEGA, B. F. New enzyme-linked immunoassay for the detection of specific antibodies against multiple Leptospira serogroups in bovine sera. Comparative Immunology, Microbiology and Infectious Diseases, Oxford, v. 75, p. 101609, 2021.

MCBRIDE, A. J. A.; ATHANAZIO, D. A.; REIS, M. G.; KO, A. I. Leptospirosis: current opinion in infectious diseases. Current Opinion in Infectious Diseases, Southampton, v. 18, n. 5, p. 376386, 2005.

MONICA, N. I.; RATHINASABAPATHI, P.; RAMYA, M. Development of real-time loop-mediated isothermal amplification (RealAmp) method for sensitive and rapid detection of pathogenic and nonpathogenic Leptospira. Letters in Applied Microbiology, Oxford, v. 68, n. 2, p. 196-203, 2019.

MUSSO, D.; LA SCOLA, B. Laboratory diagnosis of leptospirosis: a challenge. Journal of Microbiology, Immunology and Infection, Taipei, v. 46, n. 4, p. 245-252, 2013.

NAGALINGAM, M.; THIRUMALESH, S. R. A.; KALLESHAMURTHY, T.; NIHARIKA, N.; BALAMURUGAN, V.; SHOME, R.; SENGUPTA, P. P.; SHOME, B. R.; PRABHUDAS, K.; RAHMAN, H. Comparative evaluation of recombinant LigB protein and heat-killed antigen-based latex agglutination test with microscopic agglutination test for diagnosis of bovine leptospirosis. Tropical Animal Health and Production, Edinburg, v. 47, n. 7, p. 1329-1335, 2015.

NAJIAN, A. B. N.; FOO, P. C.; ISMAIL, N.; KIM-FATT, L.; YEAN, C. Y. Probe-specific loop-mediated isothermal amplification magnetogenosensor assay for rapid and specific 
detection of pathogenic Leptospira. Molecular and Cellular Probes, Amsterdam, v. 44, p. 63-68, 2019.

PHILIP, N.; AFFENDY, N. B.; MASRI, S. N.; YUHANA, M. Y.; THAN, L. T. L.; SEKAWI, Z.; NEELA, V. K. Combined PCR and MAT improves the early diagnosis of the biphasic illness leptospirosis. PloS One, Cambridge, v. 15, n. 9, p. e0239069, 2020a.

PHILIP, N.; AFFENDY, N. B.; RAMLI, S. N. A.; ARIF, M.; RAJA, P.; NAGANDRAN, E.; RENGANATHAN, P.; TAIB, N. M.; MASRI, S. N.; YUHANA, M. Y.; THAN, L. T. L.; SEGANATHIRAJAH, M.; GOARANT, C.; GORIS, M. G. A.; SEKAWI, Z.; NEELA, V. K. Leptospira interrogans and Leptospira kirschneri are the dominant Leptospira species causing human leptospirosis in Central Malaysia. PLoS Neglected Tropical Diseases, San Francisco, v. 14, n. 3, p. e0008197, 2020 b.

PICARDEAU, M. Diagnosis and epidemiology of leptospirosis. Médecine et Maladies Infectieuses, Grenoble, v. 43, n. 1, p. 1-9, 2013.

PICARDEAU, M.; BERTHERAT, E.; JANCLOES, M.; SKOULOUDIS, A. N.; DURSKI, K.; HARTSKEERL, R. A. Rapid tests for diagnosis of leptospirosis: current tools and emerging technologies. Diagnostic Microbiology and Infectious Disease, Stanford, v. 78, n. 1, p. 1-8, 2014.

PODGORŠEK, D.; RUŽIĆ-SABLJIĆ, E.; LOGAR, M.; PAVLOVIĆ, A.; REMEC, T.; BAKLANZ.; PAL, E.; CERAR, T. Evaluation of real-time PCR targeting the lipL32 gene for diagnosis of Leptospira infection. BMC Microbiology, Mainz, v. 20, n. 1, p. 1-9, 2020.

RAO, M.; AMRAN, F.; AQILLA, N. Evaluation of a rapid kit for detection of IgM against Leptospira in human. Canadian Journal of Infectious Diseases and Medical Microbiology, Vancouver, v. 2019, p. 1-4, 2019.

REVISTA DO CENTRO BRASILEIRO DE ESTUDOS DE SAÚDE. Rio de Janeiro: Órgão Oficial do Cebes, v. 38, n. 102, 2014.

RIBEIRO, M. A.; SOUZA, C. C.; ALMEIDA, S. H. Dot-ELISA for human leptospirosis employing immunodominant antigen. The American Journal of Tropical Medicine and Hygiene, Deerfield, v. 98, n. 6, p. 452-456, 1995.

ROMERO, E. C.; BLANCO, R. M.; YASUDA, P. H. Aseptic meningitis caused by Leptospira spp diagnosed by polymerase chain reaction. Memórias do Instituto Oswaldo Cruz, Rio de Janeiro, v. 105, n. 8, p. 988-992, 2010.

SENGUPTA, M.; PRABHAKAR, A. K. P.; SATYENDRA, S.; THAMBU, D.; ABRAHAM, O. C.; BALAJI, V.; CHEN, H.-W.; CHAO, C.-C.; CHING, W.-M.; PRAKASH, J. A. J. Utility of loop-mediated isothermal amplification assay, polymerase chain reaction, and elisa for diagnosis of leptospirosis in South Indian patients. Journal of Global Infectious Diseases, Tampa, v. 9, n. 1, p. 3, 2017.

SHEKATKAR, S.; ACHARYA, N. S.; HARISH, B. N.; PARIJA, S. C. Comparison of an in-house latex agglutination test with IgM ELISA and MAT in the diagnosis of leptospirosis. Indian Journal of Medical Microbiology, New Delhi, v. 28, n. 3, p. 238, 2010.

SHUKLA, S.; MITTAL, V.; SINGH, P.; SINGH, A. Evaluation of TaqMan based real-time PCR assay targeting LipL32 gene for leptospirosis in serologically positive human urine samples from north India. Indian Journal of Medical Microbiology, New Delhi, v. 39, n. 1, p. 11-14, 2021.

SILVA, L. B. da. Identificação de proteases de leptospiras envolvidas na degradação de proteínas da matriz extracelular e do plasma humano. 2017. 66 f. Tese (Doutorado em Epidemiologia) - Universidade de São Paulo, São Paulo. 2017.

Silvestrini, A. R.; PAES, A. C.; DE CAStro, A. M. M. G. Emergência de zoonoses em desastres: Relato de caso de leptospirose em Brumadinho, Minas Gerais. PUBVET, Londrina, v. 15, p. 143, 2020.

TAN, J.; KHANG, T. F.; NGEOW, Y. F.; CHOO, S. W. A phylogenomic approach to bacterial subspecies classification: proof of concept in Mycobacterium abscessus. BMC Genomics, London, v. 14, n. 1, p.1-3, 2013.

TORGERSON, P. R.; HAGAN, J. E.; COSTA, F.; CALCAGNO, J.; KANE, M.; MARTINEZ-SILVEIRA, M. S.; GORIS, M. G. A.; STEIN, C.; KO, A. I.; ABELA-RIDDER, B. Global burden of leptospirosis: estimated in terms of disability adjusted life years. Plos Neglected Tropical Diseases, San Francisco, v. 9, n. 10, p. e0004122, 2015.

TUBALINAL, G. A. SP.; BALBIN, M. M.; VILLANUEVA, M. A.; DOMINGO, C. Y. J.; MINGALA, C. N. Evaluation of LAMP for detection and/or screening of Leptospira spp. infection among domestic animals in the Philippines. Journal of Advanced Veterinary and Animal Research, Mymensingh, v. 5, n. 4, p. 459, 2018.

VAN BELKUM, A.; TASSIOS, P. T.; DIJKSHOORN, L.; HAEGGMAN, S.; COOKSON, B.; FRY, N. K.; FUSSING, V.; GREEN, J.; FEIL, E.; GERNER-SMIDT, P.; BRISSE, S.; STRUELENS, M. Guidelines for the validation and application of typing methods for use in bacterial epidemiology. Clinical Microbiology and Infection, London, v. 13, p. 1-46, 2007.

VANASCO, N. B.; JACOB, P.; LANDOLT, N.; CHIANI, Y.; SCHMELING, M. F.; CUDOS, C.; TARABLA, H.; LOTTERSBERGER, J. Diagnostic accuracy of an IgM enzymelinked immunosorbent assay and comparison with 2 polymerase chain reactions for early diagnosis of human leptospirosis. Diagnostic Microbiology and Infectious Disease, Stanford, v. 84, n. 4, p. 292-297, 2016.

VARNI, V.; RUYBAL, P.; LAUTHIER, J. J.; TOMASINI, N.; BRIHUEGA, B.; KOVAL, A.; CAIMI, K. Reassessment of MLST schemes for Leptospira spp. typing worldwide. Infection, Genetics and Evolution, Amsterdam, v. 22, p. 216-222, 2014.

VEDHAGIRI, K.; VELINENI, S.; TIMONEY, J. F.; SHANMUGHAPRIYA, S.; VIJAYACHARI, P.; NARAYANAN, R.; NATARAJASEENIVASAN, K. Detection of LipL32-specific IgM by ELISA in sera of patients with a clinical diagnosis of leptospirosis. Pathogens and Global Health, London, v. 107, n. 3, p. 130-135, 2013.

VIJAYACHARI, P.; AHMED, N.; SUGUNAN, A. P.; GHOUSUNNISSA, S.; RAO, S. R.; HASNAIN, S. E.; SEHGAL, S. C. Use of fluorescent amplified fragment length polymorphism for molecular epidemiology of leptospirosis in India. Journal of Clinical Microbiology, Washington, v. 42, n. 8, p. 3575-3580, 2004. 
VINCENT, A. T.; SCHIETTEKATTE, O.; GOARANT, C.; NEELA, V. K.; BERNET, E.; THIBEAUX, R.; ISMAIL, N.; MOHD KHALID, M. K. N.; AMRAN, F.; MASUZAWA, T.; NAKAO, R.; AMARA KORBA, A.; BOURHY, P.; VEYRIER, F. J.; PICARDEAU, M. Revisiting the taxonomy and evolution of pathogenicity of the genus Leptospira through the prism of genomics. PLoS Neglected Tropical Diseases, San Francisco, v. 13, n. 5, p. e0007270, 2019.

WAGGONER, J. J.; BALASSIANO, I.; ABEYNAYAKE, J.; SAHOO, M. K.; MOHAMED-HADLEY, A.; LIU, Y.; VITALBRAZIL, J. M.; PINSKY, B. A. Sensitive real-time PCR detection of pathogenic Leptospira spp. and a comparison of nucleic acid amplification methods for the diagnosis of leptospirosis. PLoS One, Cambridge, v. 9, n. 11, p. e112356, 2014.

WAGGONER, J. J.; PINSKY, B. A. Molecular diagnostics for human leptospirosis. Current Opinion in Infectious Diseases, Southampton, v. 29, n. 5, p. 440, 2016.
WHO. Human leptospirosis: guidance for diagnosis, surveillance and control. Geneva: World Health Organization, 2003. Disponível em: $\quad<$ https://apps.who.int/iris/bitstream/handle/10665/42667/ WHO_CDS_CSR_EPH_2002.23.pdf; sequence=1>.

WHO. Diseases Leptospirosis Burden Epidemiology Reference Group (LERG). Geneva: World Health Organization. 2018. Disponível em: <http://www.who.int/zoonoses/diseases/lerg/en/ index $2 . h t m l>$.

WOLSKA, K.; SZWEDA, P. Genotyping techniques for determining the diversity of microorganisms. In: ÇALIŞKAN, M. (Ed.). Genetic diversity in microorganisms. London: IntechOpen, 2012. p. 53-94. 